\title{
Youthful escapes: British students, overseas education and the pursuit of happiness
}

\section{Johanna Waters, Rachel Brooks and Helena Pimlott-Wilson}

\begin{abstract}
This paper draws upon the findings of a recent project examining the motivations of UK students seeking higher education overseas, to argue that notions of fun, enjoyment and the pursuit of happiness abroad featured strongly in young people's stories. Several students wanted to escape the UK, particularly the rigidity of British higher education; the perceived flexibility of a liberal arts education in North America was extremely appealing. Others saw education overseas as a chance for personal reinvention. In contrast to recent media, academic and policy accounts, which have forcefully stressed the negative effects of education-related pressures upon young people, in this paper, we argue that it is possible to see 'education' as offering up new possibilities for fun and excitement. Our research shows that, for many British students, the strategic accumulation of cultural capital was not a primary concern. Rather, perceptions of an international education were closely tied to the anticipation of excitement, fun, adventure, and escape.
\end{abstract}




\section{Youthful escapes: British students, overseas education and the pursuit of happiness}

\section{Introduction}

'[To maintain a 'playful seriousness' about life] one has to belong to the ranks of those who have been able, not necessarily to make their whole existence a sort of children's game, but at least to maintain for a long time, sometimes a whole lifetime, a child's relation to the world' (Bourdieu, 1984: 54).

'I kind of picture myself just being a lot happier, but I'm not unhappy it's just I know I could be happier, if you know what I mean?' (Joseph, British sixth-former, wants to study in the USA)

In many parts of the world (throughout East and Southeast Asia, North America and Europe), young people are under immense pressure to 'succeed'. Success is defined in different ways, but accomplishment in education - entry into the 'best' schools and universities and the accumulation of academic credentials - is possibly one of the most significant and universal measures. Over the last twenty years, a societal shift has occurred around education, so that obtaining a university degree has become a normal expectation for many young people (representing the 'democratisation' or 'massification' of higher education). Other forms of distinction in education therefore come in to play (Bourdieu, 1984; Brown, 1995) - gaining a place at and achieving a degree from a top ranking, prestigious university, for example. Pressures on young people to succeed in education are often closely connected to (middle-class) parental anxieties around social reproduction (Bourdieu, 1984; Collins, 1979; Katz, 2008; Vincent and Ball, 2007). Consequently, many adults hold a great deal of 'hope' in the possibilities of childhood (Kraftl, 2008).

Uncertainties related to social reproduction are not only expressed by adults, but young people themselves are increasingly anxious regarding their futures, displaying 'ongoing insecurities about labour market position' (Brooks, 2006: 298) and obsessing about 'employability' and the need to secure 'positional advantage' through education (Brown and 
Hesketh, 2004). Perhaps unsurprisingly, as the search for cultural capital through education has accelerated and intensified, so the possibilities and capacities for youthful enjoyment and unfettered play have correspondingly receded (Jeffrey, 2009). We concur with Jeffrey (2009: 5), who has argued that education is increasingly a 'contradictory resource' for young people, providing social opportunities whilst at the same time causing 'widespread stress and burnout'. Accounts of extreme academic competition, normalising such childhood pressures, are extensive in areas of East and Southeast Asia (Postiglione, 1997; Whitehead, 2002; Yeung 2002). In the United Kingdom, examinations have generally played a less pernicious role in formal secondary schooling, but they took on a heightened importance after the first national tests for 11- and 14-year olds (Standard Attainment Tests or SATS) were introduced by the Conservative government in 1994 (Smithers, 2007). Currently, 9.5 million children a year in England undertake SATS. They have been directly blamed for undermining the 'wellbeing' of pupils (Blair, 2007), exposing children to avoidable 'pressures' and 'stress' (Curtis, 2008; Sellgren, 2007).

In light of these concerns, this paper responds, in part, to a call made by Evans (2008), within her recent review of geographies of youth/young people. Here, she suggests that there is scope for a more explicitly 'youthful' geography, which 'engages with young people's experiences around issues of fun, exuberance, and the excitement of new opportunities and possibilities' (Evans, 2008: 1675). Here, we argue that it is possible to see 'education' as offering up new possibilities for fun (or, at the very least, that education and fun need not be completely incompatible). Our research on young British people seeking higher education overseas has shown that, for some more privileged individuals, pressures to get into Oxbridge are intense, and failure to do so has led them to seek an 'acceptable alternative' abroad (at Ivy league institutions) (Brooks and Waters, 2009). However, for other young adults within this same cohort, such strategies centred on the accumulation of cultural capital were not a 
primary reason for looking overseas (Waters and Brooks, 2010). Rather, an international education was closely tied to the anticipation of excitement, fun and adventure. More importantly, it could also be seen as a means of 'escape', from manifold pressures and expectations within the UK system. The notion of escape in relation to international education has an important spatial dimension. Indeed, the ability to move is paramount.

In this paper, then, we draw upon the accounts of British students choosing to go overseas for higher education and examine their reasons for doing so. Often a desire to leave the UK behind, whether temporarily or more permanently, was significant. Our research is based on interviews with 85 young people who were either seriously considering studying overseas at undergraduate or postgraduate level, or had completed a degree abroad. We wanted to understand why. We found that stresses, pressures and restrictions attached to a British education were significant motivations. Discourses of escape, freedom, fun and adventure permeated interview transcripts. Before elaborating on our findings, we begin with a discussion of, in the words of Cindi Katz (2008: 10), the 'production of children as accumulation strategies'. We then briefly consider the state of contemporary literature on young people and (international) mobilities, before outlining our research methods. These sections provide the context for an examination of the research, which we discuss in terms of 'flexible learning' and 'seeking solace and happiness through escape'.

\section{Young people and the accumulation of cultural capital}

Cindi Katz (2008) has recently described contemporary childhood as a 'site of accumulation'. Responsibility for social reproduction has gradually shifted from the state, to the individual and his/her family. This has resulted in an increased investment (material and emotional) in children and a concomitant 'scramble' to ensure that one's offspring 'make it' (Katz, 2008). Childhood forms of competition have intensified, particularly around school 
(and even pre-school) entry, and examinations. The immense social pressures to be found in exam-driven cultures are well known outside the West, and are particularly evident within East and Southeast Asia, where key examinations (such as the Certificate of Education Examination (HKCEE) in Hong Kong and the College Scholastic Ability Test (CSAT) in South Korea) are given 'life or death' status, and the results are displayed publically for all to see (Waters, 2008). ${ }^{1}$ These pressures have, until relatively recently, been largely muted in discourses around children and young people in Western societies, although, as noted above, in the UK at least this changed somewhat following the introduction of national tests (SATS). SATS (Standard Attainment Tests) results have been used in the production of school league tables, entrenching a discourse of parental 'choice' around state education (Gibson and Asthana, 1998). The pressures on children to do well in national examinations have consequently multiplied, and reports suggest the harmful effects upon young people's wellbeing. Teachers' unions in England are to ballot their members on a boycott of SATS, which have already been scrapped in Scotland and Wales (BBC News, 2010). A House of Commons (Children, Schools and Families) select committee recently concluded that children in England are 'among the most tested in the world' (Curtis, 2008: 10; see also a UNICEF report (2007), in which the UK came bottom of a league table of 21 industrialised countries for child well-being).

Children and young adults, then, can increasingly be seen as 'sites' for the accumulation of cultural capital (Bourdieu, 1986; Katz, 2008; Vincent and Ball, 2007). In addition to institutionalised cultural capital (i.e. formal academic credentials), they are expected to engage in varied and unusual extra-curricular activities, creating in themselves the rounded (and ultimately 'successful') individual (Brown, 1995; Devine, 2004; Vincent and Ball,

\footnotetext{
${ }^{1}$ Attitudes towards schooling and exams, however, would seem to vary by ethnic group and by class (see Louie, 2006; Portes and Macleod, 1996).
} 
2007). This 'embodied' cultural capital or 'symbolic capital' (Bourdieu, 1986) has been eloquently described by Aihwa Ong (1999), who implicitly invokes the concept of 'childhood as accumulation' in relation to cosmopolitan Chinese subjects in the contemporary diaspora. In Ong's (1999) account, the children of wealthy Chinese émigrés are actively involved in the accumulation of cultural capital through a host of activities - piano playing, dancing, singing, tennis - to enable their participation 'in the social activities of upper-class life' (Ong, 1999: 88). Similarly, although this time in a UK context, Vincent and Ball (2007) have described the role that 'enrichment activities' for 'under-fives' play in the reproduction of the middleclasses. Activities included music, ballet, gym, French and drama. They write: 'The child here is understood as a project - soft, malleable and able to be developed and improved, with the 'good' parent presenting a myriad of opportunities and support for the child to have a range of learning experiences' (Vincent and Ball, 2007, 1065). Ultimately, these activities represent the accumulation of embodied cultural capital in the child.

In relation to this, geographer Cindi Katz (2008:12) has written:

'Each of these arenas of practice around children is meant to groom their competitive advantage, casting them as an accumulation strategy. But given the relentlessness of these practices as cultural forms, they also affect the child's production of self and propel the erosion of one of the cherished hallmarks of childhood, the intrinsic nature of its pleasures.'

Amongst the young adults who we interviewed for our research, capital accumulation was commonly described in terms that made it appear 'relentless' (many engaging in endless curricular and extra-curricular activities). The potential effects of these practices upon the 'production of self' and the erosion of youthful 'pleasures' were apparent, prompting some to 
consider the opportunities for escape. Before examining this in more detail, we first return briefly to the 'spatial' dimension of students' decision making and consider their (international) mobility.

\section{Young people's mobilities}

It is now widely recognised that research on migration has, historically, neglected children's and young people's perspectives (Bushin, 2008; Dobson, 2009; Skelton, 2009). For various reasons - methodological and/or conceptual - researchers have tended not to see the significance of children as agents in migration, nor, consequently, have they asked young people about their migration experiences. With some exceptions, this is generally still the case, as a cursory look at very recent work on 'mobilities' shows (Barker et al., 2009). However, examples where young people's voices are heard are significant. They suggest the ways in which we might incorporate young people into migration/mobilities research, at the same time as demonstrating how work on children's geographies could embrace the concept of mobility more fully (Conradson and Latham, 2007; Hinton, under review, Holdsworth and Morgan, 2005; Holdsworth, 2009; Waters, 2003; Young, 2004).

One of the ways in which perspectives on mobilities and young people's experiences can be brought together is through a consideration of how mobility is utilised in the construction and reconstruction of the self. Conradson and Latham's (2007) analysis of the relationship between transnationalism and 'affect' has shown just that; mobility and young people's identities are closely related. In their research, they examine the motivations and experiences of a group of youthful skilled migrants from New Zealand working in London. They write:

'relocation to the United Kingdom is only partly about employment opportunities...

[London] is also attractive to Antipodean transnationals because it enables a certain 
degree of experimentation and exploration, whether in career or personal terms. Within a place some distance from 'home', the self can be worked upon in modest but nonetheless significant ways' (Conradson and Latham, 2007: 232).

They highlight recent academic work that has surmised 'the use of travel as a route into new forms of selfhood' (Conradson and Latham, 2007: 232) and develop this discussion to incorporate the experiences of young adults.

Recent work on international students also brings together ideas around 'youth' and 'mobilities': this is a burgeoning area of study, which has examined young people in higher education, and has included the consideration of issues around 'capital accumulation' (Balaz and Williams, 2004; King and Ruiz-Gelices, 2003; Murphy-Lejeune, 2002; Waters, 2008;). The focus of most of the research to date, however, has been on the mobility of non-Western students. Until recently, almost nothing was known about the motivations and experiences of students from Western countries such as the UK, choosing to undertake their higher education overseas. It was this that we sought to explore in our study. A recently completed project, discussed in Findlay and King (2010), estimates that approximately 24,859 UK students are presently studying abroad (as part of the Erasmus programme or for a degree). The Times Higher Education Supplement featured a small article on UK students overseas, suggesting that 'unprecedented numbers of British teenagers are considering shunning UK universities for US colleges in the hope of a broader, cheaper and more luxurious education' (Shepherd, 2006, no pagination). The Fulbright Commission, which funds study in the US, reported 700,000 inquiries in 2007, which represents a three-fold increase on the previous year (Shepherd, 2006). There is, therefore, some evidence now to suggest that the numbers of UK students interested in overseas study are not insignificant. Our research explores this issue qualitatively. We consider the intersections of 'youth' and 'mobilities'. 


\section{Prolonging youth through escape?}

According to Jeffrey and McDowell (2004: 135), critical research on youth has described how: "uncertainties in transitions to adulthood may be changing the temporal extension of notions of youth within different sections of society. A lengthening of processes of youth transition is widely attributed to more extended periods spent in formal education and delays in young people moving out of home or forming long-term, stable relationships'. Many young people, then, are actively attempting to prolong aspects of their youth. This has arisen, in part, from anxieties surrounding employment. Yet, whilst it is clear that delaying 'leaving home', for example, may reflect an attempt to prolong the security attached to being 'young' (Holdsworth and Morgan, 2005), the role of migration or long-distance mobility in the prolonging of youth experiences is more contentious. Travel is, and has been, most obviously related to biography building and establishing independence from parents (see King and Ruiz-Gelices, 2003; Conradson and Latham, 2005). To our knowledge, very little has been said of the potential role of international travel in attempts amongst young people to prolong experiences of childhood and youth. In this paper, we draw upon in-depth interviews with students and graduates to argue that for many, studying for a degree abroad was perceived not primarily as a means of securing particular credentials and, consequently, a step towards employment and adulthood. Rather it was viewed as a chance to 'escape' the pressures and expectations of their educational trajectory in the UK and to prolong the freedoms associated with youth. We were told: '[studying overseas] fitted in well because, of course, it meant a guaranteed four year pass out of employment....I just didn't want to work' (Richard, graduate, studied in Canada); and 'I didn't have any idea what I wanted to do for a career...I think I thought I'd worked really hard, I worked hard at school, I worked hard at university, and I just thought I wanted some time having some fun.' (Alice, graduate, studied in Canada). 
The notion of an overseas education was imbued with expectations of excitement, adventure and, for some, solace. It was also about avoiding the unavoidable transition into work.

The ways in which childhood and youth are prolonged are often importantly differentiated by social-class. There is an interesting relationship between 'leaving home' and class background - Holdsworth and Morgan (2005) quote Berrington and Murphy (1994), who have described a 'U-shaped' association linking class and moving out of the parental home in the UK; young people from the most and least privileged backgrounds leave at younger ages. In both cases, this is linked to the perceived need (material or psychological) to acquire greater independence and to speed up the transition to adulthood. Staying at home, therefore, is concomitantly associated with attempts to prolong one's youth. There is also a strong, related association between social class and the propensity to plan for the future - including the decision to leave or stay at home and to further one's education (Brannen and Nilsen, 2002; Brooks and Everett, 2008; Du Bois Reymond, 1998).

The relationship between young people's international mobility and class is unambiguous - international (educational) mobility is overwhelmingly pursued by privileged individuals (Findlay and King, 2010; Brooks and Waters, 2009; Waters and Brooks, 2010). British students who choose to go abroad for higher education are able to suspend the inevitable (for them) move towards the responsibilities of work and career for a short time, at least, and consequently to prolong their youth. Bourdieu (1984) has argued that the ability to prolong experiences of youth is a function of 'distance from economic necessity'. To maintain a 'playful seriousness' about life, Bourdieu (1984) writes, 'one has to belong to the ranks of those who have been able, not necessarily to make their whole existence a sort of children's game, but at least to maintain for a long time, sometimes a whole lifetime, a child's relation to the world' (54). For the majority of British overseas students, their privileged upbringings are critical. 


\section{Research methods}

This paper draws upon a recent research project, funded by the British Academy, which has used qualitative research methods to examine the 'international' educational experiences of UK students. Specifically, we conducted in-depth interviews with 85 young people -40 individuals seriously considering undertaking an overseas degree (20 at undergraduate level and 20 at postgraduate level) and 45 individuals who had completed the whole of an undergraduate or postgraduate degree abroad. ${ }^{2}$ Amongst other things, we wanted to understand how and why UK students made the decision to study overseas at university-level (as opposed to remaining in the UK): the factors that informed this decision; the social and familial context underpinning their choices; and the importance of social class. This paper focuses in particular upon the reasons students gave for choosing an 'overseas education'.

Taken as a whole, the socio-economic characteristics of our respondents indicate that international students from the UK represent a highly privileged group, with access to significant amounts of capital (social, cultural and economic) (this assertion is supported by another recent, large-scale survey by Findlay and King, 2010). Privilege was demonstrated in a number of different ways: in the extent of parental support and involvement in students' education; in familial expectations with regard to educational achievement; and in the amount/quality of capital invested by the family in students' learning (Coleman 1988). It was evident that students encountered significant pressure (from schools, peers and families) to attend a 'prestigious' university. Prior experiences of travel (as a child or youth) - whether on family or school trips, as part of a 'gap year' or as a 'year abroad' within an undergraduate

\footnotetext{
${ }^{2}$ Participants were recruited through different channels, including the Fulbright Commission, the Canadian Rhodes Scholars Foundation, the Commonwealth Scholars Commission, 65 alumni associations, university notice pages, and state and private schools in the UK (within Surrey, Greater Manchester, Merseyside and Cumbria).
} 
degree programme - were clearly important. In what follows, we discuss the objectives of UK students, which were often expressed not in terms of 'employability' or career-oriented goals, nor in terms of the explicit accumulation of cultural capital, but instead depicted notions of escape, enjoyment, and future happiness.

We should also, briefly, mention the geography of students' choices: all of the sixthformers interviewed were seriously considering the United States as a study destination for an undergraduate degree. Of the 11 individuals interviewed who had completed an undergraduate degree overseas, five had studied in the US, two in Canada, and one in Ireland, France, Japan and South Africa. We also interviewed 20 undergraduates seriously considering studying overseas for a postgraduate degree. The US was named as a possible study destination 15 times, compared with only three mentions given to the Netherlands, Sweden and Australia. Finally, to those individuals (34) who had completed a postgraduate degree overseas - the most popular destinations were: Canada (9), the US (8), Italy (6) and Australia (5). Our findings support those of the Sussex Centre for Migration (2004), which describe the popularity of North American and Australasian destinations, and the desire for study in English. We begin our empirical analysis with a discussion of the opportunities afforded by a different pedagogical system - namely, the North American liberal arts system - and the implications of this for the prolonging of youth.

\section{Flexible learning}

It is interesting to observe that, with the internationalisation of higher education, differences between national systems have become more apparent and significant. This is the case despite various moves towards 'standardisation' in education (such as, for example, the 
Bologna process $^{3}$ and international quality assurance measures introduced by UNESCO). In her work on the transnational migration of students between Hong Kong and Canada, Waters (2008) emphasises the salience of contrasting pedagogical styles. Employers in Hong Kong, she argued, had a preference for a North American pedagogy, promoting creativity and critical thinking, as opposed to the emphasis on 'rote-learning' that still pervades university teaching in East Asia. Consequently, a degree from a Canadian university was considered 'more valuable' for many occupations. These important differences can often get subsumed within 'internationalisation' discourses that stress convergence upon a fictional universal model of higher education.

This section considers the importance, as voiced by several research participants, of international differences in pedagogical styles in their decision to go overseas for higher education. Over half of all the sixth-formers interviewed discussed the importance of the US liberal arts system, and highlighted this as a major reason why they wanted to study abroad.

In the UK, students have to choose their degree programme - usually one degree programme - at the age of 17 or 18 , during A-level ${ }^{4}$ study or equivalent. For some individuals, we unexpectedly found, this caused tremendous disquiet; as one participant said, echoing others: 'I feel quite uneasy in making the decision...' (Alicia, sixth-former). Several expressed the view that they were being tied into a particular career trajectory at a very young age, in fact before they knew what they wanted to do. They felt rushed into making this critical decision, with very little support or relevant guidance. The following quotations illustrate the general tenor of their arguments:

\footnotetext{
${ }^{3}$ The Bologna Process is a European reform process aimed at creating a European Higher Education Area, based on international cooperation and exchange.

${ }^{4}$ A-level is 'Advanced level' study, pursued between the ages of 16 and 18 in the UK.
} 
'I think it [the US system] just gives you more time to decide what I want to do with my life, and I don't think at this age you really know exactly what you want to do.' (Hamza, sixth-former, wants to study in the USA).

'I guess it's the liberal arts education, so I don't have to say right now exactly what I want to do. I'm going to get the chance to go out there and try out again all the things that I had to drop when I was 14, and all the things I had to drop when I was 16, you know? ... That's why, one of the big reasons I'm applying to the States... And I think, I still think 18 is quite an early time to choose... We've got to make these choices at 14 [for GCSEs ${ }^{5}$ ], we then make choices at 16 [for A-levels] as to where exactly we want to go.... Just not having to make exact choices right now is one of the biggest pros.' (Darren, sixth-former, wants to study in the USA).

Recently, a small amount of press coverage in the UK has highlighted the potential benefits of the liberal arts system, including the notion that it better meets the needs of British employers. A few universities in the UK are beginning to offer a BA in liberal arts (St Mary's University College, Belfast and Winchester University, and UCL (University College London) will begin trialling a four-year liberal arts degree in 2011). 'The English model', one newspaper article reports, involves 'a narrowing of focus through A-levels and then further narrowing at university' (Tahir, 2010, 8). These ideas were clearly reflected in our findings, and represented a major reason why UK students were choosing to study in the United States.

\footnotetext{
${ }^{5}$ GCSE stands for General Certificate of Secondary Education. These examinations are taken by most 16 yearolds in the UK.
} 
The flexibility offered by the North American higher education system appealed to individuals on two levels. Some students were clearly afraid of making an irretrievable, lifedefining mistake when it came to deciding on a degree programme:

'You can afford to make mistakes [in the US], whereas here [UK] if you like go for a course in history, and you realise it's the wrong thing... the likelihood is that you're going to have to drop out and re-apply and then do your four years again...' (Kamil, sixth-former, wants to study in the USA).

For others, the issue was less about fear and more about the freedom, enjoyment and excitement that comes from being able to try out a range of subjects before committing to any particular one:

'This is really something that is quite exciting that I would like to do... It looks like it's enjoyable to do because their normal degrees are four years, but their first year... you're not focussing on a specific subject, a bit like you decide on bits of ones that you'd like to do....And then in your second year you choose your major. So I would like to major in the science side, but I suppose, I think it's a lot nicer, the fact that in your first year you can have a 'taster' of everything and then you can really say, well actually I've completely misconstrued what I thought it was going to be like, so great, I'll major in something else now.' (Jessica, sixth-former, wants to study in the USA).

'Really and truly, you may not know what you want to do, and you start your degree and your realise this ain't for you, and that's money and time, and that's a major issue I think.' (Dominic, sixth-former, wants to study economics in the USA). 
On the whole, the students we interviewed were critical of the UK education system, perceiving it as narrowly exam-driven, and their claims chimed with widespread media reports on the problems associated with SATS in England. In contrast, higher education in the United States offered a 'different way of learning' - where 'achievement' takes account of a whole performance:

'A lot of their grades [in the United States] are not... 'sit down and write a test'. It's more like how you do throughout the whole [year], like, all your lessons.... To be honest, I think that's a bit more fair ... In England...you do, like, a whole year or three years of education, and then the whole three years is based on a one hour, two hour exam. But the way they do it [in the US], it's based on how you do, like, the whole time you're there.' (Keiran, sixth-former, wants to study international business in the USA).

In the following quotation, Linda raises several apposite points. She demonstrates the extreme pressures experienced by some British students to excel academically (where a 'high B' at A-level is not good enough) and how studying in North America will offer her a 'second shot' at getting where she wants to go (Brooks and Waters, 2009). She also emphasises a 'general attitude' to education in North America that is different from the UK, where the results of one examination are never decisive:

'I'm thinking about studying in America primarily because of the courses, just the general attitude that they have to education, to valuing your extra-curriculars, valuing you as a person rather than just your academic ability. For example, I wanted to study English eventually but in my A levels I got a B, so granted it was a high B, but it's not 
good enough to get me into any universities here to do straight English...So, I mean, I know eventually I could major in English eventually in America. And having got a B in English, which I know if a really good grade, but coming from my school you're expected to get three As and I expected myself to get there As. Thus, getting a B-I wasn't upset, even though I was...but I can still major in English, which is a really comforting fact.' (Linda, sixth-former, wants to study English in the USA).

British students, then, are considering overseas study at degree level for a number of pedagogical reasons, which include the opportunity to pursue "a broader range of subjects" (Fiona, sixth-former); assessment criteria based on a more holistic educational experience (and not just on summative exams); and the ability to 'wait and see' about the choice of degree programme. We would argue, however, that the North American liberal arts system also enabled young people to delay, if for only a short time, the march toward adult commitments and responsibilities, whilst extending their experience of youth.

\section{Seeking solace and happiness through escape}

The notion of 'escape,' when attached to an overseas education, has more than one significant meaning. We have discussed how the decision to go abroad for higher education (particularly to the United States) may be tied to a desire for a different learning experience. Others, however, also invoked 'escape', but these individuals were less concerned about accessing a specific pedagogy than with responding to a more general feeling that they wanted to leave the UK behind and seek out a happier life abroad. This sentiment is captured in the following replies to the question 'why are you thinking of studying overseas?' 
'I want to study overseas number one because I want to get as far away from London as possible and I'm not fond of London.' (Hamza, sixth-former, wants to study in the USA).

'I dunno, I'm 20 years old, I just feel like I've been in England too long. I feel like there's more to experience than just England and I've been to a lot of English universities and... I don't really like English people as people. I'm very proud to be English but I don't really like England if you know what I mean?' (Joseph, sixthformer, wants to study in the USA).

In some cases, the desire to leave the UK was, amongst other things, linked to negative perceptions of British university culture, where drinking to excess is considered normal behaviour (Jayne et al., 2008). The following student reflected upon the multiple reasons why he felt the need to go elsewhere for his higher education:

'Things in England are a bit more... focused on the drinking and a bit more focused on the social things of going out and partying all night and not really working. And I spoke to my friend who went to Massachusetts University and he said it's totally different to here you know, they'll go out once a week and have a big party but the party always ends at a certain time, people are always at home at a certain time, you know where to find people. Whereas uni life here is a lot different whereas you can just go out until four or five in the morning and totally forget about the next day. I don't know, I guess I'd just find it a lot easier to study abroad, I wouldn't have any distractions with anybody that I knew or anything that I perhaps don't like about this 
country I know that I won't find abroad.' (Joseph, sixth-former, wants to study in the USA).

This sentiment was repeated on several occasions, reflecting the desire for a more 'rounded' university experience that is less focussed on 'get[ting] absolutely smashed' (Jessica, sixthformer, wants to study in USA). Some individuals had more personal reasons for wanting to escape to a happier life overseas. Fiona said (referring to her parents' recent divorce): 'One of the appeals of America is that it's a completely new slate. You just wipe everything clean. Nobody knows your history unless you want them to.' Others talked in broader terms of the 'opportunities' (employment and otherwise) that would be available to them abroad. Dwight's portrait of the USA is clearly an idealised one:

'I think there's a lot more freedom in America than there is over here. There's a lot more jobs available in America, less competition for certain jobs in America than there are over here. There's like uncapped success in America and like uncapped opportunities whereas over here you can only get to a certain point before your success is limited in a way' (Dwight, sixth-former, wants to study in the USA)

We should not dismiss the power of such discourses in shaping migration decisions - seven out of the 20 sixth-formers and 12 out of twenty undergraduates interviewed for our project discussed the possibility of living permanently overseas following their studies. Education would provide an essential basis for this move:

'I think that going to an American university and setting up that foundation for me to move over there. It's a massive investment, but it's going to pay off in the sense that it 
will give me a steady foundation for living in America and a good education, which will hopefully help me get a good job in America and eventually earn more than I could have been doing or more success and live a happier life than if I hadn't have gone.' (Dwight, sixth-former, wants to live in the USA)

The search for a 'happier life' is an important but overlooked reason why students may choose to go abroad for their education, when so much of the emphasis in the literature is on employability and career-linked objectives.

\section{Conclusion}

Young people are today faced with manifold pressures and expectations related to academic achievement and the creation of a rounded, accomplished 'self' (Brown, 1995; Vincent and Ball, 2007). Something is lost, however, with such a stifling emphasis on 'success' (Katz, 2008); youthful exuberance and the joys of childhood have been significantly downplayed (if not totally neglected) in recent accounts of young people's geographies (Evans, 2008). In this paper, we have suggested that the pursuit of education and fun, enjoyment and adventure are not always incompatible. Indeed, we have described a situation where alternative choices around higher education might enable young people to find their 'youthful' selves. Young British people, we argue, attempt to delay the onset of adulthood (and the responsibilities that entails), in response to various uncertainties, in different ways (Jeffrey and McDowell, 2004). For the individuals interviewed for our research, this involved the relatively unusual decision to study and live overseas.

Going to university abroad entails an element of long-distance travel, enabling students to escape, through mobility, their former lives and start anew (Conradson and Latham, 2005). In many cases, there were specific pedagogical reasons for choosing the USA for higher 
education - amongst sixth-formers, the liberal arts system was especially appealing, allowing individuals to delay thinking about a future career trajectory and instead to have fun trying out different courses and subjects. The ostensible lack of emphasis on terminal examinations at universities in North America was another reason for going abroad and for leaving the UK behind. Other students wanted simply to escape the pressures and expectations attached to life in the UK, and to find solace and a 'happier life' elsewhere. Invoking Bourdieu (1984), these students exuded a 'playful seriousness', understanding the gravity and inevitability of life after education (involving responsibility, hard work and career) and yet, at the same time, wanting to postpone this transition to adulthood. Their (middle) class status has been critical to their ability to prolong their youth. Interestingly, even though many of these students may not have been searching for cultural capital or some sort of 'positional advantage' (Brown and Hesketh, 2004) in the labour market, as recent media coverage has suggested, a liberal arts education (in addition to the embodied experiences of living abroad) can make them more appealing to employers in the UK. In this case, fun and enjoyment and the (un)strategic accumulation of cultural capital may in fact go hand in hand. 


\section{Bibliography}

Barker, J., P. Kraftl, J. Horton and F. Tucker 2009. The road less travelled - new directions in children's and young people's mobility. Mobilities 4(1): 1 - 10 .

Balaz, V. and A. Williams. 2004. 'Been there, done that': international student migration and human capital transfers from the UK to Slovakia. Population, Space and Place 10: 217 - 237.

BBC News 2010. SATS boycott ballot for teachers. BBC News. http://news.bbc.co.uk/go/pr/fr/-/1/hi/education/8479426.stm. Accessed 11th February 2010.

Blair, A. 2007. Wellbeing of pupils 'sacrificed in the pursuit of results' The Times Friday June 22, p. 38.

Bourdieu, P. 1984. Distinction; a Social Critique of the Judgement of Taste. Cambridge Massachusetts: Harvard University Press.

Bourdieu, P. 1986 The forms of capital. In J. G. Richardson (Ed.). Handbook of Theory and Research for the Sociology of Education (pp. 241 - 258).NY: Greenwood Press.

Brannen, J. and A. Nilsen. 2002. Young people's time perspectives: from youth to adulthood. Sociology, 36 (3): 513 - 537.

Brooks, R. 2006 Learning and work in the lives of young adults. International Journal of Lifelong Education 25 (3): 271 - 289.

Brooks, R. and G. Everett. 2008. The prevalence of 'life-planning': evidence from UK graduates. British Journal of Sociology of Education 29: 325 - 337.

Brooks, R. and J. Waters. 2009.

Brooks, R. and J. Waters 2009. 'A second chance at success': UK students and global circuits of higher education. Sociology 43 (6): 1085 - 1102.

Brown, P. 1995. Cultural capital and social exclusion: some observations on recent trends in education, employment and labour market. Work, Employment and Society 9: 29 - 51.

Brown, P. and A. Hesketh. 2004. The Mismanagement of Talent: Employability and Jobs in the Knowledge Economy. Oxford: Oxford University Press.

Bushin, N. 2008 Quantitative data sets and children's geographies: examples and reflections form migration research. Children's Geographies 6 (4): 451 - 457.

Coleman, J. 1988. Social capital in the creation of human capital. American Journal of Sociology 94: S95 - S120.

Collins, R. 1979. The Credential Society: an Historical Sociology of Education and Stratification. New York: Academic Press. 
Conradson, D. and A. Latham. 2005. Friendship, networks and transnationality in a world city: Antipodean transmigrants in London. Journal of Ethnic and Migration Studies 31 (2): 287- 305.

Conradson, D. and A. Latham. 2007. The affective possibilities of London: Antipodean transnationals and the overseas experience. Mobilities 2 (2): $231-254$.

Curtis, P. 2008 School tests system under great stress, says exam chief. The Guardian, Tuesday July $15^{\text {th }}$, p. 10 .

Dobson, M. 2009. Unpacking children in migration research. Children's Geographies 7 (3): 355- 360 .

Du Bois Reymond, M. 1998 'I don't want to commit myself yet': young people's life concepts Journal of Youth Studies 1 (1): 63 - 79.

Evans, B. 2008. Geographies of Youth/Young People Geography Compass, 2 (5): 1659 1680 .

Findlay, A., R. King, A. Stam and E. Ruiz-Gelices. 2006. Ever reluctant Europeans: the changing geographies of UK students studying and working abroad. European Urban and Regional Studies 13: 291 - 318.

Findlay, A. and R. King 2010 'Motivations and experiences of UK students studying abroad' BIS Research Paper No. 8, University of Dundee

Gibson, A. and S. Asthana 1998. School performance, school effectiveness and the 1997 white paper. Oxford Review of Education 24 (2): 195 - 211.

Hinton, D. under review 'Wales is my home': higher education aspirations and student mobility in Wales' Children's Geographies

Holdsworth, C. And D. Morden 2005 Transitions in context: leaving home, independence and adulthood Berkshire: Open University Press

Holdsworth, C. 2009. 'Going away to uni': mobility, modernity, and independence of English higher education students Environment and Planning A 41 (8): 1849 - 1864

Jayne, M., G. Valentine and S. Holloway. 2008. Fluid boundaries - British binge drinking and European civility: alcohol and the production and consumption of public space. Space and Polity 12 (1): 81 - 100.

Jeffrey, C. 2009. Geographies of children and youth I: eroding maps of life Progress in Human Geography Online First.

Jeffrey C. and L. McDowell, 2004 'Youth in a comparative perspective: global change, local lives' Youth and Society 36 (2): $131-142$. 
Katz, C. 2008. Childhood as spectacle: relays of anxiety and the reconfiguration of the child. Cultural Geographies 15: 5 - 17.

King, R. and E. Ruiz-Gelices. 2003. International student migration and the European 'yearabroad': effects on European identity and subsequent migration behaviour. International Journal of Population Geography 9: 229 - 252.

Kraftl, P. 2008 Young people, hope, and childhood-hope Space and Culture 11 (2): 81 - 92

Louie, V. 2006 Compelled to Excel: Immigration, Education and Opportunity among Chinese Americans California: Stanford University Press.

Murphy-Lejeune, E. 2002. Student mobility and narrative in Europe: the new strangers. Routledge: London and New York.

Ong, A. 1999. Flexible Citizenship: the cultural logics of transnationality. Durham, Duke University Press.

Portes, A. and D. MacLeod 1996. Educational progress of children of immigrants: the roles of class, ethnicity, and school context. Sociology of Education 69 (4): 255 - 275.

Postiglione, G. A. 1997. Schooling and social stratification (pp. 137 - 154). In Postiglione G. A. \& Lee, W. O. (Eds.). Schooling in Hong Kong: Organization, Teaching and Social Context. Hong Kong: Hong Kong University Press.

Sellgren, K. 2007. Tests 'reduce pupils to widgets' $B B C$ News http://news.bbc.co.uk/go/pr/fr/-/1/hi/education/662677.stm. Accessed 15th January 2010.

Skelton, T. 2009. Children's geographies/geographies of children: play, work, mobilities and migration. Geography Compass 3(4): 1430 - 1448

Smithers, A. 2007 Blair's Education: an international perspective The Sutton Trust.

Sussex Centre for Migration Research. 2004. International Student Mobility. University of Sussex.

Tahir, T. 2010. The thinking person's degree? Education Guardian, Tuesday January $19^{\text {th }}: 8$.

UNICEF, 2007. Report card 7, Child Poverty in Perspective: An Overview of Child Wellbeing in Rich Countries. UNICEF Innocenti Research Centre, Florence.

Waters, J. L. 2003 ' 'Satellite Kids' in Vancouver: transnational migration, education and the experiences of lone children' in Michael W. Charney, Brenda S.A. Yeoh and Tong Chee Kiong (eds.) Asian Migrants and Education: The Tensions of Education in Immigrant Societies and among Migrant Groups London: Kluwer Academic Publishers: 165 - 184.

Waters, J. L. 2008. Education, Migration and Cultural Capital in the Chinese Diaspora: transnational students between Hong Kong and Canada. New York: Cambria Press 
Waters, J. L. 2009. In pursuit of scarcity: transnational students, 'employability', and the MBA. Environment and Planning A 41 (8): 1865 - 1883

Waters J. and R. Brooks. 2010. Accidental achievers? International higher education, class reproduction and privileged in the experiences of UK students overseas. British Journal of Sociology of Education 31 (2): 217 - 228.

Whitehead, K. 2002. Grades aren't everything. South China Morning Post. Wednesday November $2^{\text {nd }}$. Archive (n.p.).

Yeung, L. 2002. HKU joins fight to curb rising suicides. South China Morning Post Saturday May $4^{\text {th }}$. Archive (n.p.).

Young, L. 2004. Journeys to the street: the complex migration geographies of Ugandan street children. Geoforum 35: 471 - 488. 